Received: 22/05/2019

Revision: 28/11/2019

Accepted: 05/12/2019

OnlineFirst:29/01/2020

\title{
An In-depth Qualitative Study of Teachers' Role Identities: A Case of Iranian EFL Teachers
}

\section{Pouria Aghaei}

Department of English Language, Shiraz Branch, Islamic Azad University, Shiraz, Iran, pouria_aghaei@yahoo.com

\section{Mohammad Bavali}

Department of English Language, Shiraz Branch, Islamic Azad University, Shiraz, Iran, mbvl57@gmail.com

\section{Fatemeh Behjat}

Department of English Language, Abadeh Branch, Islamic Azad University, Abadeh, Iran,fb_304@yahoo.com

EFL teacher's identity plays a significant role in the construction of teachers' characteristics in educational settings. In the Iranian EFL context, the study of teachers' role identity has been given more attention in recent years. The present study has two objectives. First, it aimed to investigate Iranian EFL teachers' perception of their role identity. The study also intended to determine the dominant role identities among participants. To this end, 19 Iranian EFL teachers were chosen through purposive sampling from three universities in Shiraz, Iran. Three data collection methods including semi-structured interview, classroom observation and narrative inquiry were used to collect data. The data were analyzed through Wellington's (2000) staging method. The findings revealed that various EFL teachers' role identities could be categorized under three main themes of teacher as a manager, professional and acculturator based on Farrell's (2011) model. The results of chi-square analysis also revealed that two role of teacher as a knowledge transmitter and caregiver were more dominant EFL teachers' role identities among Iranian EFL teachers in the present study. The findings can have pedagogical implications for EFL teachers, educators and educational staff to better understand teachers' role identities in various contexts.

Keywords: EFL teacher role identity, narrative inquiry, staging analysis, teacher education, teacher identity 


\section{INTRODUCTION}

Identity development has become an increasingly important area of study in the field of teacher education and instruction. According to Reeves (2017), identity construction and development is a lifelong process. Teacher identity development is influenced by many factors such as personal and professional experiences as well as current teaching contexts (Olsen, 2008). Investigating about how a language teacher identity is developed over time is significant since it provides insight into how language teaching is carried out. As put by Varghese, Morgan, Johnston, and Johnson (2005, p. 22), "in order to understand language teaching and learning we need to find out about various aspects of teachers' identity; and in order to understand teachers, we need to have a clearer sense of who they are: the professional, cultural, political, and individual identities which they claim or which are assigned to them". Relevantly teachers' identity directly influences how they behave and teach in every educational setting (Danielewicz, 2001). Professional identity is not a stable entity, but rather a dynamic and continuing process, developing over time and influenced by the teacher's characteristics, and prior experiences on the one hand, and professional contexts that are found relevant by teacher educators on the other. As pointed out by Kogan (2000), it can be concluded that the notion of professional identity, specifically in the field of instruction, is a matter of both social influences and person reflection. A teacher constructs a professional identity by providing a link between individual characteristics and the characteristics of the field as a whole (Pennington, 1999).

Generally speaking, role identity is a psychological term, which means one tends to be the same with other individuals or groups through imitating and internalizing the behavior manner, attitudinal notion and value criteria. Teacher role identity was first coined by Farrell (2008) and defined as "how teachers recognize their roles within their world and involve their beliefs, values, and assumptions about teaching and being a teacher" (p. 55). Thus, teachers' role identity is a process through recognizing oneself between social and self-identity. The construction and establishment of teacher's professional role identity is influenced by many factors such as institutional power, social and cultural norms in the society and social and self-portrait on career development. Role identity provides teachers with a framework that implicitly guides them in interpreting and evaluating experiences and events related to teaching, and in making decisions about action (Horn, Nolen, Ward \& Campbell, 2008).

The notion of professional role identity shares the landscape with the concept of professional development. There is evidence in the research literature that professional role identities are developed mainly through engaging in activities of professional development (Devos, 2010). Also, as noted by Jones (2004), issue of teacher professional role identity are deep rooted and can be seen to have effects on the way teachers cope with professional developments. This suggests the need for in-depth professional development that recognize $\mathrm{s}$ the role and impact of teacher professional identity.

Because of the increasing number of English language teachers on the one hand, and the globalization of English on the other hand, today more important than ever the issue of 
language teacher identity is particularly salient for the teacher who is not a native of the second or foreign language being taught" (Nunan, 2017). Consequently, the postmodern era in language education not only needs teachers who completely know their roles in relation to other stakeholders in their field, but also favors those who make an extra effort to be recognized as professionals. Furthermore, the post-modern teaching education needs teachers who can cope better with ever-increasing challenges in the field. Undoubtedly, professional teachers are much more successful in this path.

Although a lot of concern has been made on the construction of professional role identity in western countries, very little is known about the Iranian context. Also, as elaborated by Miller (2009), some aspects of teacher's role identity are still undiscovered. Besides, current empirical studies reveal that most EFL teachers in Iran neither know about the fundamental criteria for being a professional teacher, nor do they try to identify their multi-dimensional role as a professional teacher (Sahragard \& Sadeghi, 2017). There is an increasing focus on teacher professional identity in education globally. Since teachers' professional identity experiences are the central part of their teaching practice and their commitment as professionals (Burn, 2007; Day, Elliot, \& Kington, 2005), an investigation on teachers' role identity has great implications for curriculum reform, classroom teaching, and student learning (Caihong, 2011). The lack of sufficient practical studies regarding various role identities of EFL teachers in Iranian educational settings reveals the necessity for conducting the current study. Moreover, according to Park (2012), most studies on teachers' professional role identity only focus on native pre-service teachers' professional identity construction in their homelands, and the nature of professional and role identity of experienced and non-native EFL teachers was neglected. Moreover, the question that remains unsolved in the field of teacher education is what the dominant roles among EFL teachers are in an Iranian context.

Day by day we witness that the English language is used by more people as their second language (ESL) or foreign language (EFL) in the world. In Iran, as an EFL context, thousands of English language teachers are working in the educational system with each one of them having different identities, but little attention has been paid to 'role identity construction'. The other problem is how these teachers synthesize this process of identity construction with their role as language teachers. The outcomes of the current research can be significant in various ways. Firstly, it can expand the existing literature on EFL teacher role identity in Iranian educational setting in the sense that the findings add new roles to the previously found ones. Secondly, since professional role identity in this study has been investigated using various instruments such as interviews and observations, it can enrich the existing findings regarding the nature and construction of EFL teacher professional identity. Last but not the least, on a smaller scale, this study is also significant to the improvement of teacher education within Iranian educational contexts.

Therefore, the current study aims to answer the following questions:

1. What is Iranian EFL teachers' perception of their role identity?

2. Which role identities are more dominant for Iranian EFL teachers? 


\section{LITERATURE REVIEW}

Similar to the notion of identity itself, the term 'teacher identity' is not uniformly defined (Beijaard, Meijer, \& Verloop, 2004; Izadinia, 2013), yet it is also complex in nature and encompasses various elements. Beijaard et al. (2004) concluded in their literature review that past research has defined the concept of teacher identity contradictorily or not at all. Pennington (2015) conceptualized teacher identity as "a construct, mental image or model of what 'being a teacher' means that guides teachers' practices as they aim to enact 'being a teacher' through specific 'acts of teacher identity"' (p. 17). This theory is fundamentally based on how teachers define themselves and view their identities in relation to their background and educational system. Pennington (2015) believed that teachers' self-image directly influence how they enact in classes and how they possess their roles in teaching path. Furthermore, this notion affects how teachers interact with stakeholders such as students, staff and colleagues in the educational setting. Barkhuizen (2017) also tried to provide a concise construction regarding the concept of language teachers' identity. He stated that language teacher identities are social, emotional, ideological, and historical, and they are both inside the teachers' mind and also exist in the social and technological world outside. These elements are constantly accepted, rejected, acknowledged and valued by either the teachers themselves or others in the field. They are core and peripheral, personal and professional, they are dynamic, multiple, hybrid, and they are foregrounded and backgrounded. Taken together, it is indicated that teacher identity is related to teacher's self-image at present or future and connected to educational setting and stakeholders in the field.

Although there are some variations regarding the definition of teacher identity from different viewpoints, there are some common matters in terms of what are outstanding factors which influence the construction of teacher identity. For example, Flores and Day (2006) in their study came to conclusion that various factors such as personal and professional histories, pre-service training, and school culture and leadership all determine the stability of teachers' professional identities. In line with this theory, Beauchamp and Thomas (2009) argued that teacher identity is shaped and reshaped through interactions with others in a professional context. They also argue that teachers' identity development "involves an understanding of self and a notion of that self within and outside contexts such as a classroom or school, necessitating an examination of self in relation to others" (p. 178). In a similar fashion, Martel and Wang (2014), in their literature review on language teacher identity, explain that interactions with significant others, personal biographies, and individual contexts significantly shape the construction of language teacher identity. The influence of past memories or prior experience on the formation of teacher identity has also been highlighted in many researchers' work (e.g, Chang-Kredl \& Kingsley, 2014; Lamote \& Engels, 2010. In her review of literature on pre-service teachers' professional development, Izadinia (2013) found that there are four broad factors affecting pre-service teachers' identity development in teacher education programs which are reflective activities, participating in communities of learning, the contexts in which teacher learning occurs, and prior experiences. In addition to agreement on the influencing factors regarding the concept of teacher identity, reviewing 
the existing literature also reveals some other common features. Teacher identities are dynamic in nature and not predetermined. Also, teacher identity is socially situated. Teacher identity is completely distinguished from teacher 'role', Teacher identity is a process as well as a product and finally teacher identity is a constant relationship among teacher, history, professional contexts and other relevant stakeholders in the educational setting.

Roles are often considered to be constructions of identity and particularly professional identity. Role is a concept through which it is easier to conceive the items that identity is built of. Different scholars have defined roles variously. As an example, for Arikoski (1999), roles are defined by and based on the position one happens to be in a community or a group. Individuals also naturally tend to change their roles according to place, people and group because different roles are to facilitate interplay among people (Arikoski, 1999). Thus, it is possible to expect that teachers have different roles even inside the classroom. Role expectations can be generally acknowledged norms of society. In the teacher profession, students can be seen as complementary role partners and cases of headmasters, parents and other teachers as role partners and all role partners and stakeholders in an educational setting have expectations towards each other. Similarly, Wright (1987) defined roles to be social. They are constructed of factors that together produce certain social behaviour. Some roles can be avoided, some fall on us randomly and some are chosen, such as profession. According to Wright (1987), misunderstandings and contradictions appear if the teacher is not certain of the role behaviour expected from her/him, the teacher's own expectations differ from other people's, the teacher's other roles are overlapping, the teacher's personality does not fit into the role or, the teacher simply does not believe in what $\mathrm{s} / \mathrm{he}$ is conveying.

Regarding the theoretical frameworks for teacher role identity, Farrell's (2011) is the most renowned and used one in the field. The study was exploratory and descriptive in nature to arrive at fundamental information and achieve an interpretivist perspective to address the issue of professional role identity. Farrell (2011) examined the notion of role identity among three ESL teachers in Canada. He constructed his framework to 3 main categories for teachers' role identity as follows: (a) teacher as a manager which considers how a teacher strived to manage what happened in the classroom; (b) teacher as a professional which deals with how a teacher dedicates himself or herself to his/her work, and takes it very seriously and finally (c) teacher as an acculturate which denotes that "where the teacher is seen as one who engages in activities outside the classroom and helps students become accustomed to the local culture" (Farrell, 2011, p. 58). All of these main categories have their own sub-categories. This model tried to provide a comprehensive view toward the subject of teachers' role identity from multidimensional perspectives, such as managerial, professional, and socio-cultural aspects.

\section{Related Studies Regarding Language Teacher's Professional Role Identity}

Leon-Carillo (2007) tried to explore a group of student teachers' roles by asking them to draw pictures about how they perceive a teacher and then explain them. The participants were 120 Filipino teachers. The results were categorized under five main groups of teacher roles which were knowledge source, direction-setter, character formatter, change 
agent and learner. The roles of direction-setter, character formatter and change agents were also taken as the teacher-centered perception of student teachers according to which the teacher is the active agent of the teaching process rather than the learner who takes responsibility.

Lin, Shein and Yang (2012) conducted a study surveying how 40 pre-service student teachers conceptualized themselves as English teachers at the beginning of their certificate program at a university in Taiwan. Findings revealed learner-centered beliefs. 14 participants thought that language teachers were like nurturers helping students grow. Another popular image was that of a cooperative leader who helped students as a mentor giving them some guidance when they needed. Other metaphors used were knowledge provider, artist and innovator.

Rahimi and Askari Bigdeli (2014) tried to investigate the dynamicity and flexibility of a group of Iranian in-service EFL teacher's role identity. The participants of their study were 36 experienced teachers from various institutes. The data were gathered through semi-structured interview. Their findings revealed that the most recurring teacher role identity was teacher as vendor and the least one was teacher as collaborator which showed that teachers did not share their ideas and experiences with each other.

Sahragard and Sadeghi (2017) investigated different role identities among a group of Iranian in-service EFL teachers based on Farrell's (2011) framework. Twenty-one Iranian English language teachers from three educational contexts (university, school, and institute) were interviewed and provided their written narratives. The collected data were analyzed through thematic analysis and the findings revealed that Iranian EFL teachers conceptualized their role identity from multi-dimensional perspectives, including managerial, professional, and socio-cultural perspectives.

In the same vein, Atai, Babaii and Lotfi Gascaree (2018) conducted a narrative study to explore Iranian in-service EAP teachers' cognition on their role identities. The researchers used life history narratives and teaching philosophy statements as the data collection materials. The findings of the study revealed eight different teacher role identities from 'teacher as creators' to 'teachers as observers of ethicality'.

\section{Theoretical Underpinnings for the Current Study}

In relation to the literature on teacher identity in non-English speaking contexts, most studies related to EFL teacher role identity are framed within sociocultural perspectives. A sociocultural perspective of identity argues that people are products of their social histories. It also highlights the role of interdependencies among individuals, context, history and others as well as the continuous nature of self-development. Building on the usefulness of sociocultural theories for investigating teacher identity and taking a socially constructed perspective, a sociocultural approach to identity in framing the study was adopted. Looking at the issue through this lens, identity formation must be viewed as shaped by and shaping forms of action, involving a complex interplay among cultural tools. 


\section{METHOD \\ Design of the Study}

The present study used a qualitative design to explore how a group of Iranian EFL teachers think about their professional role identities and also which roles were more dominant among the teachers. To answer the first research question, a qualitative research method was chosen by the researchers to collect the data and analyse it. Qualitative research method is appropriate for studies which are intended to answer how and why research questions (Yin, 2009). Also, according to Norton and McKinny (2010), qualitative paradigm is an appropriate method for investigating the process of identity construction. Moreover, the present research followed Bogdan and Biklen (2007) who asserted that qualitative studies seek to primary focus on participants' perspectives, and there is an emphasis on process rather than outcomes. Furthermore, a quantitative analysis was employed to answer the second research question.

\section{Participants}

The participants of the current study were 19 Iranian EFL teachers (including 12 males and 7 females) from three universities in Shiraz, Iran. This study was a part of a larger $\mathrm{PhD}$ dissertation project. The study lasted for about 7 months (from winter 2018 to summer 2019). The participants were chosen based on purposive sampling procedure since it is more appropriate for qualitative studies regarding better and deeper achievement of understanding (Patton, 2002). The age range was between 23 to 38 years old. The participants were categorized into two groups of novice and experienced teachers based on their years of teaching experiences. The participants were $\mathrm{PhD}$ candidates and M.A or PhD graduates.

\section{Data Collection Procedure}

After selecting the participants, they were informed about the objectives and aims of the study. The data collection for this study was done through a semi-structured interview, narrative inquiry and classroom observations. The researchers used these three types of data collection methods in order to have a deep and comprehensive view of the issue. According to Wellington (2000), triangulation gives the researchers more insights from various angles which can result in more generalizability and trustworthiness of the results.

\section{Semi-structured interviews}

During the semi-structured interviews, the participants were asked about their viewpoint regarding the concept of identity in language teaching profession and also how they perceive and define their professional role as EFL teachers in and outside the educational setting. The interview questions were developed by the researchers and for ensuring the validity and trustworthiness the interview questions were refined by taking two expert views. The interview questions included questions about professional identity of teachers and also their personal beliefs and experiences. All of the interviews were held at the teacher's offices or their classrooms. The researchers also got the participants' consent to record the interviews. The interview questions were refined by taking two expert views. Interview sessions mostly last between 1 to 2 hours. All the interviews were recorded by the researchers and then transcribed. 


\section{Narrative inquiry}

The teachers were also asked to write about their personal experiences and beliefs as a personal narrative method. Farrell (2011) argued that teachers can propose their different roles through stories, diaries and biographies. Observation as a data collection strategy allows researchers to make sense of the context from the perspectives of the participants and to get a better grasp of the norms and expectations in a setting (Hatch, 2002). In this way, researchers could compare what participants say and do and realize some taken for granted points participants may never remember to comment on (Bogdan \& Biklen, 2007).

\section{Observation}

In the observation phase, the researchers tried to observe the participants' involvement both in classroom environment as well as their behavior outside the classroom setting including meetings with other colleagues or staff. Observation can provide information about different types of setting. In the current study, since the aim of the researchers was to discover the roles of EFL teachers, the human settings (characteristics of teachers) and the interactional settings (interaction between teachers and learners) were the main settings which the researchers investigated. The observation phase played a kind of complementary role for the interviews and helped the researchers foster their understanding of the issue. In so doing, an observation checklist was used by the researchers to collect the outstanding points during the observation sessions.

\section{Data Analysis Procedure}

The analysis of the quantitative phase of the study included both descriptive (frequency and percentage) and inferential (chi-square) statistics. The chi-square analysis was employed to investigate which roles were more dominant among Iranian EFL teachers. For analysing the qualitative data of the study, when the data from interviews, narrative inquiries and observations were collected, they were transcribed for further analysis. For analyzing the gathered data, the researchers adopted Wellington's (2000) staging of data analysis since it considered as an appropriate way of analysing qualitative data. Wellington (2000) provided a kind of cyclical process for analyzing the data. The data were analysed through Wellington's (2000) staging through the following phases:

1. The first phase was immersion. In this stage, the researchers read the data several times and took notes. The researcher reread the data meticulously and checked if any data went unnoticed based on the main categories.

2. The second phase was reflection. This stage dealt with rereading the data, and then putting the data away for a while and then going through them again in case anything has been missed in the first stage.

3. The third phase was analysis. In this stage, the data were broken down into separated categories, and each category was given a separate name. Also the similar categories were merged together. The data were coded based on the key terms used by participants which presented each category of role identity. The codification processes were done based on the theoretical frameworks such as Wright (1987), Wenger (1998), and Farrell (2011). 
4. In the last phase which was synthesis stage, the separated data were ready for comparison and contrast. The similar data were united, and different ones were broken down into different categories. These data were juxtaposed in this stage in order to find out the differences and similarities with existing literature.

A similar procedure was used for the analysis of narrative inquiries and notes from classroom observations. After finishing these phases, the researchers categorized the data under the main categories of teacher roles based on Farrell's (2011) model.

\section{FINDINGS}

\section{Findings for the First Research Question}

As mentioned in the previous section, the theoretical framework adapted by the present study was Farrell's (2011) model of language teachers' role identity. As a result, the researchers categorized the emerging EFL teachers' role identities under three main theme of this model in the following table:

Table 1

The Emerging Role Identities Bon Farrell's (2011) Model

\begin{tabular}{|c|c|c|}
\hline Teacher as manager & Teacher as professional & Teacher as acculturator \\
\hline $\begin{array}{l}\text { Knowledge transmitter } \\
\text { A teacher who just transfer the } \\
\text { knowledge from authorities to } \\
\text { learners }\end{array}$ & $\begin{array}{l}\text { Community Builder } \\
\text { A teacher who exchange the latest } \\
\text { information and technologies in } \\
\text { the field with colleagues }\end{array}$ & $\begin{array}{l}\text { A Caregiver } \\
\text { A teacher who cares about his-her learners' } \\
\text { daily life in and outside the classroom }\end{array}$ \\
\hline $\begin{array}{l}\text { Artist } \\
\text { A teacher who has the art of } \\
\text { entertaining, telling jokes and } \\
\text { creating new games }\end{array}$ & $\begin{array}{l}\text { Reflective Practitioner } \\
\text { Teachers who are knowledge } \\
\text { producers and offer solutions } \\
\text { for emerging problems }\end{array}$ & $\begin{array}{l}\text { Cultural Mediator } \\
\text { A teacher who helps learners to know the } \\
\text { foreign language social and cultural } \\
\text { setting }\end{array}$ \\
\hline $\begin{array}{l}\text { Scaffolder } \\
\text { A teacher who helps learners go } \\
\text { beyond their potential } \\
\text { capacities }\end{array}$ & $\begin{array}{l}\text { Action Researcher } \\
\text { A teacher who constantly investigate } \\
\text { teaching process in order to } \\
\text { improve students' learning }\end{array}$ & $\begin{array}{l}\text { Moral Educator } \\
\text { A teacher who enhances learners' social } \\
\text { and emotional skill development }\end{array}$ \\
\hline $\begin{array}{l}\text { Innovator } \\
\text { A teacher who is ready to create } \\
\text { new learning techniques and } \\
\text { materials }\end{array}$ & $\begin{array}{l}\text { Entrepreneur } \\
\text { A teacher who involves in the } \\
\text { extended school life and try to } \\
\text { answer its challenges }\end{array}$ & $\begin{array}{l}\text { Counselor } \\
\text { A teacher who is always ready to listen to } \\
\text { learners and give appropriate solution }\end{array}$ \\
\hline $\begin{array}{l}\text { Motivator } \\
\text { A teacher who motivates learners in } \\
\text { different ways }\end{array}$ & $\begin{array}{l}\text { Expert } \\
\text { A teacher with great subject matter } \\
\text { knowledge }\end{array}$ & $\begin{array}{l}\text { Empathyzer } \\
\text { A teacher who can act as an intimate friend } \\
\text { and develop empathy with students }\end{array}$ \\
\hline $\begin{array}{l}\text { Facilitator } \\
\text { A teacher who facilitate the whole } \\
\text { learning process for learners }\end{array}$ & $\begin{array}{l}\text { Learner } \\
\text { A teacher who is constantly learning } \\
\text { new things in the field }\end{array}$ & \\
\hline
\end{tabular}

\section{Teacher as knowledge transmitter}

Despite of the postmodern language teaching pedagogy, it seems that EFL teachers in Iranian educational context still adopt the role of a knowledge transmitter. The following example is from a classroom observation of a male teacher with 6 years of experience:

In one of the observation sessions, one of the researchers observed that teacher had to finish the pre-determined text-book and materials which have been presented by the institutional authorities; it seems that the teacher doesn't have any right to question the curriculum or change them in anyway. Families of learners also ask teachers to teach learners just based on the institutional programs. (classroom observation) 
A female novice teacher also wrote:

I think it is too bad for language teachers that they cannot have critical thinking on the choice and implementation of the course materials, even sometimes authorities don't give any opportunity to teachers for stating their opinions about the relevance and appropriateness of the chosen curriculum... (narrative inquiry)

It is crystal clear from the above-mentioned statements that a considerable number of EFL teachers are not satisfied with their role as just a passive teacher who transmits the pre-determined knowledge and program to learners.

\section{Teacher as an artist}

One of the important roles in managing the classroom setting is teacher as an artist. It takes account of the art of teacher in entertaining and managing the classroom setting. As one of the experienced teachers wrote:

To me, during the past years, the emphasis in the process of instruction had changed from teaching to learning. Hence, I prefer to manage the classroom using a variety of stimuli because I already recognized that my students learn best in groups. To make a long story short, the key point is not to let the students get bored... (narrative inquiry)

\section{Teacher as a scaffolder}

The findings revealed another role which was the role of teacher as a scaffolder. The teacher adopts this role in learner-centered classrooms, and based on sociocultural theory, he tries to help learners to go beyond their current level and improve their learning. Here is an example from a classroom observation:

During observation in a general English course, the researcher noticed that the teacher started the lesson through describing the same concept in multiple ways for the learners. Later on, he shifted to visual aids since a considerable number of learners needed more help with understanding the topic. (classroom observation)

\section{Teacher as an innovator}

This role identity was emergent through researchers' observations. The following example is from an observation from a novice teacher's classroom:

The researcher noticed that the teacher had a unique project for each of the grammatical points he taught to the learners. These projects varied from a single paragraph text to small homemade booklets. (classroom observation)

\section{Teacher as a facilitator}

This role is one of those ready-made roles that almost all of novice and experienced teachers have. As one of the novice teachers wrote:

I allocate a considerable time to guide students in learning for themselves and forming their thoughts and ideas. By providing resources and then interactive monitoring of their progress followed by encouragements, the students reach at more open-ended discoveries and learn to manage their own learning... (narrative inquiry) 


\section{Teacher as a community builder}

Another significant role which has been emerged through the interview sessions was teacher as a community builder. As a male experienced teacher with 9 years of teaching experiences stated:

You know, we, as experienced teachers, try to exchange our knowledge with each other. Moreover, sometimes I share my work day with other teachers and talk about students' needs and behaviors. Also, once or twice a month we try to have conversation about the latest articles in the field together, I think this can help us become much more professional teachers... (interview)

\section{Teacher as a reflective practitioner}

Teacher as a reflective practitioner was the other emergent role identity. Here is one of the experienced teacher's statements:

You know...I always want to improve my teaching profession. So, I try to reflect on my own teaching even by having a small chat with my students after classes to see how well or bad things are going on in my class. If I face a problem in my teaching path, I try to ask colleagues, checking out relevant sources in the field and finding the solution... (interview)

This emergent role identity is definitely in the opposite direction of teacher as a knowledge transmitter. Unlike teacher as knowledge transmitter who only tries to pass the received knowledge and pre-determined program to learners, teacher as a reflective practitioner tries to have creativity, critical thinking and most importantly reflectivity.

\section{Teacher as an action researcher}

The other emergent role identity which was categorized under the main theme of professional is action researcher. Mostly the experienced teachers had shown the characteristics of using triangulation and reflectivity in their teaching method. The following is one of the examples of observing a classroom of a male teacher with 9 years of experience:

In observing a non-homogeneous university classroom, the researcher observed that whenever the teacher faced with a challenging teaching situation or a problematic issue, he asked the students to propose their opinions. He also made notes during the teaching and also followed a trial and error method to come up with the appropriate solution. (classroom observation)

\section{Teacher as a learner}

The findings revealed that more experienced teachers adopted this type of role identity. The following is a narration from a teacher with 8 years of experience:

As an experienced teacher, during these years of my teaching career, I figured out that a language teacher is not a know-it-all person. So, I never stopped learning myself. I take TEFL or TTC courses to update myself each year... (narrative inquiry)

\section{Teacher as a caregiver}

One of the sociocultural role identities which most occurred among novice teachers was teacher as a caregiver. This is a type of pre-determined conventional role identity which 
teachers maintain since they think they must always help their learners in any situation even out of the educational context. One of novice teachers stated:

If I figure out that one of my student is sad or has some personal problem, I try to talk to him after the class time and you know... try to find a solution for real-life problems they might encounter or even talk to his parents... also I always have attempted to have an intimate relationship with my students and being a friend for them.. (interview)

\section{Teacher as a cultural mediator}

This role identity depends heavily on the mastery of language teacher over the culture and customs of the foreign language. The following example can clarify the issue:

In an observation, the researcher noticed that the teacher paid attention not only to the teaching of language functions and relevant vocabulary and grammar but also made sure the students become aware of the cultural settings of such functions. The researcher also realized that the teacher motivated learners' social integration and participation through acquiring the foreign language cultural skills along with other language skills. (classroom observation)

\section{Teacher as a moral educator}

Another emergent role identity which could be categorized under the main theme of acculturator is teacher as moral educator. One of the experienced teachers wrote:

I think teachers can establish a respectful relationship with students through adhering to ethical criteria. In my POV, teaching is not just providing students with lessons and information. Teachers should also try to have the power of developing learners' right attitudes...I, myself, always try to act as a good role model for my students... (narrative inquiry)

\section{Findings for the Second Research Question}

The second research question concerned which role identities are more dominant in each role identity groups among the Iranian EFL teachers in the present study. To address the question, the researchers calculated the frequency and percentage of each role identity. Furthermore, a chi-square test was run to investigate if the frequency differences were statistically significant.

Table 2 also displays the distribution of roles based on the 'teacher as manager' subheading.

Table 2

The Distribution of Roles Based on 'Teacher as Manager' main Theme

\begin{tabular}{lllll}
\hline Role identities & Frequency & Percentage & Valid Percentage & Cumulative Percentage \\
\hline Knowledge transmitter & 16 & 32.6 & 32.6 & 32.6 \\
Artist & 11 & 22.4 & 22.4 & 55 \\
Scaffolder & 6 & 12.3 & 12.3 & 67.3 \\
Innovator & 3 & 6.2 & 6.2 & 73.5 \\
Motivator & 8 & 16.3 & 16.3 & 89.8 \\
Facilitator & 5 & 10.2 & 10.2 & 100 \\
Total & 49 & 100.0 & 100.0 & \\
\hline
\end{tabular}

As it is evident from the table, the role knowledge transmitter with 16 occurrences and $32.6 \%$ was the most frequent role in teacher as manager main theme. On the other hand, 
the role innovator with just 3 occurrences and $6.2 \%$ was the least frequent role identity in this main theme. Also, chi-square test was employed to find out whether the frequency differences were statistically significant. As table 3 shows, results of chisquare $\left(x^{2}(5)=13.57, \mathrm{p}=.019\right)$ indicated that the frequency differences were statistically significant for role identities in Teacher as Manager main theme.

Table 3

Chi-square test for Teacher as Manager Sub-Heading

\begin{tabular}{ll}
\hline Chi-square & $13.571^{\mathrm{a}}$ \\
\hline $\mathrm{df}$ & 5 \\
& 019
\end{tabular}

Asymp. Sig. $\quad .019$
.

a. 0 cells $(0.0 \%)$ have expected frequencies less than 5 . The minimum expected cell frequency is 8.2 .

Table 4 represents the distribution of roles in terms of the second main theme which is teacher as professional.

Table 4

The Distribution of Roles Based on 'Teacher as Professional' main Theme

\begin{tabular}{lllll}
\hline Role Identities & Frequency & Percentage & Valid Percentage & Cumulative Percentage \\
\hline Community builder & 10 & 23.8 & 23.8 & 23.8 \\
Reflective practitioner & 5 & 11.9 & 11.9 & 35.7 \\
Action researcher & 13 & 30.9 & 30.9 & 66.6 \\
Entrepreneur & 7 & 16.6 & 16.6 & 83.2 \\
Expert & 3 & 7.2 & 7.2 & 90.4 \\
Learner & 4 & 9.6 & 9.6 & 100 \\
Total & 42 & 100.0 & 100.0 & \\
\hline
\end{tabular}

Regarding teacher as professional main theme, the findings revealed that action researcher with 13 occurrences and 30.9\% was the most frequent role and expert with 3 occurrences and $7.2 \%$ constituted the least frequent role. The results of chi-square test in table 5 revealed that the frequency differences were not statistically significant for roles in teacher as professional main theme $\left(x^{2}(5)=10.57, \mathrm{p}=.061\right)$.

Table 5

Chi-square test for Teacher as Manager Sub-Heading

\begin{tabular}{ll}
\hline Chi-square & $10.571^{\mathrm{a}}$ \\
\hline $\mathrm{df}$ & 5 \\
Asymp. Sig. & .061
\end{tabular}

a. 0 cells $(0.0 \%)$ have expected frequencies less than 5 . The minimum expected cell frequency is 7.0

Table 6 illustrates the distribution of roles regarding the main theme of teacher as acculturator. 
Table 6

The Distribution of Roles Based on 'Teacher as acculturator' Sub-Heading

\begin{tabular}{lllll}
\hline Role identities & Frequency & Percentage & Valid Percentage & Cumulative Percentage \\
\hline Caregiver & 14 & 40 & 40 & 40 \\
Cultural Mediator & 2 & 5.7 & 5.7 & 45.7 \\
Moral Educator & 8 & 22.9 & 22.9 & 68.6 \\
Counselor & 6 & 17.2 & 17.2 & 85.8 \\
Empathizer & 5 & 14.2 & 14.2 & 100 \\
Total & 35 & 100 & 100 & \\
\hline
\end{tabular}

According to the table 4 , the role of caregiver with 14 occurrences and $40 \%$ comprise the most frequent role among roles under the main theme of teacher as acculturator. On the other side, cultural mediator with 2 occurrences and $5.7 \%$ was the least frequent role identity in this specific theme. As table 7 indicates, the chi-square analysis $\left(x^{2}(5)=\right.$ $11.43, \mathrm{p}=.022)$ revealed significant differences for role identities in teacher as acculturator main theme.

Table 7

Chi-Square test for Teacher as Manager Sub-Heading

\begin{tabular}{ll}
\hline Chi-square & $11.439^{\mathrm{a}}$ \\
\hline $\mathrm{df}$ & 5 \\
Asymp. Sig. & .022
\end{tabular}

a. 0 cells $(0.0 \%)$ have expected frequencies less than 5 . The minimum expected cell frequency is 7.0 .

\section{DISCUSSION}

As the findings indicated, various types of EFL teachers' role identity have been emerged through semi-structured interviews, observations of teachers' classes and also narrative inquires. The first theme based on Farrell 's (2011) model was teacher as manager and one of the main sub-categories of roles in this theme was teacher as a knowledge transmitter which could be categorized under the main theme of teacher as a manager. The chi-square analysis also revealed that this role identity was a dominant one among other roles in teacher as manager main theme. This specific sub-role was identified through class observation by the researchers. It was perceived by the researchers in the observation sessions that novice teachers only transmit the pre-fixed and pre-determined knowledge to their students without having any reflectivity or creativity. This type of EFL teacher's characteristic has originated its roots from Technicist Teacher Education. Halliday (1998) describes technicism in teacher education "as the notion that good teaching is equivalent to efficient performance which achieves ends that are prescribed for teachers" (p. 597), which is in contrast with the reflective practice. The justification of this finding may reside in the fact that Iranian EFL setting is still encourages the practice traditional teaching pedagogy. EFL teachers in pre-service programs do not become familiar with the post-modern era in language teaching. Moreover, institutional authorities somehow ask teachers just to follow a predetermined program and implement it without questioning the pre-fixed educational programs. As Kumaravadivalu (2006) stated, post-method pedagogy puts teachers at the center of language learning and values his/her beliefs and experiences. Furthermore, 
novice teachers may become teachers who just pass the knowledge without autonomy because of institutional restrictions in Iran. Since stakeholders in the field including managers and even parents want teachers to finish the pre-determined text-books based on the schedule. The results are in strong contradiction with Burns and Richards, (2009) who believe that teachers should create conditions for construction of knowledge through social participation rather than just transfer of knowledge. Also the findings are on the opposite side of Kincheloe's (2008) which suggest that technicist approach to teacher education renders teaching into a "lifeless" practice by killing the curiosity and creativity of teachers. The results were supported the findings of the study conducted by Fahim and Pishghadam (2009). They came to conclusion that in Iranian EFL context, decisions are made by authorities and there is no room for teachers' creativity and autonomy. They also believed that Iranian teachers are not allowed to air their own views.

The second main theme was teacher as a professional. Another role that has been emerged through discussions and interview sessions with experienced teachers was a new term which the researchers call community builder and could be categorized under the main theme of teacher as a professional. As it was clear from the findings, teachers with this feature are those who share the latest information, findings and research in the field with their colleagues and students. They encourage community through cooperative learning experiences and have reflectivity over the preparation and presentation of the appropriate curriculum. The findings are in line with those of Henning, Moloi, Nduna, Smit, Mebelane, Phasha, Sedebi and Pather (2006) who all claimed that successful enactment of teachers' professional identity seems to engage in various complex interactions with learners, peers, administrators and community. In the same vein, Kumaravadivelu (2012) pointed out that knowledge is shared by the members of the profession. The findings were also compatible with Wenger, McDermott and Snyder (2002) who believed that identity of language teachers are constantly changing and reshaping through participation in a community of practice.

The other role identity of EFL teachers in the present study was teacher as a reflective practitioner which is categorized as one of the main themes of professional role identities of teachers. Teachers with this feature are those who make outstanding decisions and bring their previous knowledge, beliefs and values into their teaching path. They are critical thinker and can solve emerging problems throughout the teaching procedure. For Schön (1987), classroom reality is full of unexpected problems and dilemmas and a professional teacher needs reflective action in order to cope with the problems and to find the appropriate solution. The findings are much in accord with those of (Johnson, 2009; Wallace, 1991) who believed that reflective teachers must not only receive relevant knowledge but also must be taught to use their prior experiences as learners themselves. In addition, the findings support those of Richards (1989) which asserted that teachers are continually involved in activities to reflect on their own teaching and their roles as teachers.

The next outstanding role was teacher as a scaffolder which is under the main theme of professional role identity of EFL teachers. In Vygotsky 's (1978) socio-constructivist 
theory, social interaction is very important for learners in the learning process and this interaction with teacher and other students can lead to knowledge construction. Teacher as a scaffolder helps younger learners to go beyond their current level and enhance their potential learning capacities to actual ones. The findings are in a direct line with those in the literature such as (wang, 2007; Wells, 2007) who maintained that teacher in a community of practice is someone who provides learners with the opportunities for social interaction in classroom activities.

In the present study, one of the most frequent mentioned role identities, specifically among novice female teachers was teacher as a caregiver. This type of identity is under the main theme of acculturator. Teachers with this type of role identity try to provide sociocultural support and care for their learners in and outside the educational setting. Teachers as caregivers are always ready for emotional and affective sympathy with their learners. The present study's findings regarding sociocultural role identity of EFL teachers support the previous findings in the literature such as Farrell (2011) who pointed out the role of EFL teachers as cultural adapter and those who make emotional relationship with their learners. In addition, the findings of chi-square test indicated that this role identity was dominant in teacher as acculturator main theme. In Iranian educational context, EFL teachers, especially the novice teachers, try to make an intimate relationship with their learners. These groups of EFL teachers think that by being a close friend with younger learners, they might get more credit and attention from families or institutional authorities. This is maybe why the role of caregiver was more dominant among EFL teachers in the present study.

The findings of the present study again highlight the previous findings of Sahragard and Sadeghi (2017) study. They also argued that teachers' role identities should not be viewed from just one dimension. The role identities have multi-dimensional aspects and all of them must be taking into consideration. Furthermore, the results of the study supported the findings of Rahimi and Askari Bigdeli (2014) who elaborated the point that teachers' role identities are dynamic in nature and constantly changing.

\section{CONCLUSION}

This study attempted to explore the perceptions of Iranian EFL teachers' role identities. Taken together, the findings revealed 17 emergent role identities under three main theme of teacher as manager, professional and acculturator. Moreover, the results showed that teacher as knowledge transmitter and caregiver were the dominant role identities. Teachers in different contexts, situations and environments might adopt different roles. These roles might sometimes be far from each other, and they might have overlaps at times. The various types of teachers' role do not mean that they are in an opposite direction with each other. A language teacher, depending on the circumstances in every educational setting might even adopt some of the roles simultaneously. As Nola (2016) stated, teacher's roles should not be static and English teachers must define different roles for themselves according to the classroom needs. Also as noted by Harmer (2007), it is more logical to describe various teachers' roles and say what they are appropriate for, rather than make judgments about their usefulness. According to Farrell (2011), language teacher roles can be divided into ready-made roles or roles 
which are pre-determined in nature or may be imposed by power and institutional forces. Examples of this kind of roles are teacher as knowledge transmitter or caregiver. Some other roles are those which teachers create and are intrinsically motivated in nature. These roles include teacher as a community builder or scaffolder. Moreover, teaching profession is a complicated career and teachers need to develop many of these roles together simultaneously. In other words, these roles are not in the opposite line with each other, rather they have some features in common (Kumaravadivelu, 2003). In a nutshell, the important point here is that teachers, educators and institutional staff must be aware of different types of professional roles, they need to know them an identify the influential factors which change and create these roles as well as perceiving how they can be established in a teacher's epistemological viewpoint.

\section{IMPLICATIONS OF THE STUDY}

The findings of the present study can have different pedagogical implications. Firstly, the results can shed light on the concept of role identity as a significant issue in every EFL teacher's professional career construction. Since language teachers are the most important agents in every educational system, the findings can help them to know their different roles and try to establish the appropriate roles based on emergent issues in their classroom settings. Secondly, the findings can be useful to teachers, educators and curriculum developers to provide a clearer definition and insight regarding the concept of teachers' role identity for novice teachers. Lastly, the results can be useful for institutional authorities. The findings revealed that educational members and managers play a significant role in the construction and adoption of different roles by teachers. The further studies can be carried out using valid questionnaires to collect data about teachers' role identities. Also, investigating the difference between role identities of university and institution EFL teachers would be another topic of interests for future studies.

\section{REFERENCES}

Arikoski, J. (1999). Interaction in teaching. In P. Räsänen, J. Arikoski, P. Mäntynen, \& J. Perttula. (Eds.). Teaching psychology (pp. 177-223). Finland: Public Administration Training Centre.

Atai, M. R., Babaii, E., \& Lotfi Gaskaree, B. (2018). A narrative study of in-service EAP teachers' cognition on language teacher role identities. Iranian journal of language teaching research, 6(2), 97-115.

Barkhuizen, G. (2017). Language teacher identity research. In G. Barkhuizen (Ed.), Reflections on language teacher identity research (pp. 1-11). New York: Routledge.

Beauchamp, C., \& Thomas, L. (2009). Understanding teacher identity: An overview of issues in the literature and implications for teacher education. Cambridge Journal of Education, 39(2), 175-189.

Beijaard, D., Meijer, P. C. \& Verloop, N. (2004). Reconsidering research on teachers' professional identity. Teaching and Teacher Education, 20, 107-128. 
Bogdan, R. C. \& Biklen, S. K. (2007). Qualitative research for education an introduction to theories and methods. Boston: Pearson

Burn, K. (2007). Professional knowledge and identity in a contested discipline: challenges for student teachers and teacher educators. Oxf. Rev. of Edu, 33(4), 445-467.

Burns, A., \& Richards, J. C. (2009). The Cambridge guide to second language teacher education. Cambridge University Press, New York.

Caihong, H. (2011). Changes and characteristics of EFL teachers' professional identity: The cases of nine university teachers. Chinese Journal of Applied Linguistics (Quarterly), 34(1), 3-21.

Chang-Kredl, S., \& Kingsley, S. (2014). Identity expectations in early childhood teacher education: Preservice teachers' memories of prior experiences and reasons for entry into the profession. Teaching and Teacher Education, 43, 27-36.

Danielewicz, J. (2001). Teaching selves. identity, pedagogy, and teacher education. Albany, NY: State University of New York Press.

Day, C., Elliot, B., \& Kington, A. (2005). Reform, standards and teacher identity: Challenges of sustaining commitment. Teaching and Teacher Edu., 21(5), 563-577.

Fahim, M., \& Pishghadam, R. (2009). Postmodernism and English language teaching. International Journal of Advanced Life Sciences, 1(2), 27-54.

Farrell, T. S. C. (2008). Reflective language teaching: From research to practice. Continuum, London: UK.

Farrell, T. S. C. (2011). Exploring the professional role identities of experienced ESL teachers through reflective practice. System, 39(1), 54-62.

Flores, M. A., \& Day, C. (2006). Contexts which shape and reshape new teachers' identities: A multi-perspective study. Teaching and Teacher Education, 22, 219-232.

Halliday, J. (1998). Technicism, reflective practice and authenticity in teacher education. Teaching and Teacher Education, 14(6), 597-605.

Harmer, J. (2007). The practice of English language teaching. Harlow: Pearson.

Hatch, J. A. (2002). Doing qualitative research in education settings. Albany: State University of New York Press.

Henning, E., Moloi, K., Nduna, B., Smit, B., Mebelane, V., Phasha, N., Sedebi, M., \& Pather, E. (2006). Teachers in a new dispensation: Foreign identities in varying contexts. Symposium presented at the annual meeting of the American Educational Research Associations, San Francisco.

Horn, I. S., Nolen, S. B., Ward, C., \& Campbell, S. S. (2008). Developing practices in multiple worlds: The role of identity in learning to teach. Teacher Edu. Qua., 61-72.

Izadinia, M. (2013). A review of research on student teachers' professional identity. British Educational Research J., 39(4), 694-713. doi: 10.1080/01411926.2012.679614.

Johnson, K. E. (2009). Second language teacher education: A sociocultural perspective. New York: Routledge. 
Kincheloe, J. K. (2008). Critical pedagogy. New York: Peter Lang Publishing.

Kogan, M. (2000). Higher education communities and academic identity. Higher Education Quarterly, 54(3). 207-216.

Kumaravadivelu, B. (2003). Beyond methods macro strategies for language teaching. New Haven: Yale University Press.

Kumaravadivelu, B. (2006). Understanding language teaching from method to postmethod. Lawrence Eribaum Associates.

Kumaravadivelu, B. (2012). Language teacher education for a global society. UK: Routledge.

Lamote, C., \& Engels, N. (2010). The development of student teachers' professional identity. European Journal of Teacher Education, 33(1), 3-18.

Leon-Carillo, C. D. (2007). Filipino pre-service education students' preconceptions of teacher roles viewed through a metaphorical lens. Asia-Pacific Journal of Teacher Education, 35(2), 197-217.

Lin, W., Shein, P. P. \& Yang, S. C. (2012). Exploring personal EFL teaching metaphors in pre-service teacher education. Eng. Teaching: Practice and Critique, 11(1), 183-199.

Martel, J., \& Wang, A. (2014). Language teacher identity. In M. Bigelow \& J. EnnserKananen (Eds.), The Routledge Handbook of Educational Linguistics (pp. 289-300). New York: Routledge.

Miller, J. (2009). Teacher identity. In A. Burns, \& J. C. Richards (Es.), The Cambridge guide to second language teacher education (pp. 172-181). New York: Cambridge U.

Nola, A. (2016, July 07). The 7 roles of a teacher in the 21st century. Retrieved from http://etoninstitute.com/blog/teacher-training/the-7-roles-of-a-teacherin-the-21st-century.

Norton, B., \& McKinney, C. (2010). An identity approach to second language acquisition. In D. Atkinson (Ed.), Alternative approaches to second language acquisition (pp. 73-93). New York, US: Routledge.

Nunan, D. (2017). Language teacher identity in teacher education. In G. Barkhuizen (Ed.), Reflection on language teacher identity research (pp. 164-169). New York: Routledge.

Olsen, B. (2008). How reasons for entry into the profession illuminate teacher identity development. Teacher Education Quarterly, 35(3), 23-40.

Park, G. (2012). "I am never afraid of being recognized as an NNES": One teacher's journey in claiming and embracing her nonnative-speaker identity. TESOL Quarterly, 46(1), 127-151.

Patton, M. Q. (2002). Qualitative research and evaluation methods. Thousand Oaks, CA: Sage Publications.

Pennington, M. C. (1999). Rules to break and rules to play by: Implications of different conceptions of teaching for language teacher development. In H. Trappes-Lomax, \& I. 
McGrath, (eds). Theory in language teacher education. (pp. 99-108). London: Longman.

Pennington, M. C. (2015). Teacher identity in TESOL: A frames perspective. In Y. L. Cheung, S. B. Said, \& K. Park (Eds.), Advances and current trends in language teacher identity research (pp. 16-30). New York: Routledge.

Rahimi, A., \& Askari Bigdeli, R. (2014). The dynamicity and flexibility of EFL teachers' role identities in language institutes. ABAC Journal, 34(2), 46-55.

Reeves, J. (2017). Teacher identity. TESOL Encyclopedia of English Language Teaching.

Richards, J. (1989). Beyond training: Approaches to teacher education in language teaching. Keynote address on second language teacher education, Macquarie University, Sydney, 15 June 1989.

Sahragard, R., \& Sadeghi, M. (2017). Exploring teachers' role identity among Iranian EFL teachers: a narrative-based research. International Journal of Applied Linguistics and English Literature, 6(4), 11-20.

Schön, D. A. (1987). Educating the reflective practitioner. San Francisco: Jossey-Bass.

Varghese, M., Morgan, B., Johnston, B., \& Johnson, K. A. (2005). Theorizing language teacher identity: Three perspectives and beyond. J. of Lang, Ident, and Edu, 4(1), 21-44.

Vygotsky, L. S. (1978). Mind in society: The development of higher psychological processes. (M. Cole, Ed.). Cambridge, MA: Harvard University Press.

Wallace, M. J. (1991). Training foreign language learners a reflective approach. Cambridge: Cambridge University Press.

Wang, L. (2007). Sociocultural learning theories and information literacy teaching activities in higher education. Reference and User Services Quarterly, 47(2), 149-158.

Wellington, J. (2000). Educational research contemporary issues and practical approaches. London: Continuum Books.

Wells, G. (2007). Semiotic mediation, dialogue and the construction of knowledge. Human Development, 50(5), 244-274.

Wenger, E., McDermott, R., \& Snyder, W. (2002). Cultivating communities of practice: A guide to managing knowledge. Cambridge: Harvard Business Press.

Wright, T. (1987). Roles of teachers and learners. Oxford: Oxford University Press.

Yin, R. K. (2009). Case study research, Design and methods. Thousand Oaks, CA: SAGE. 